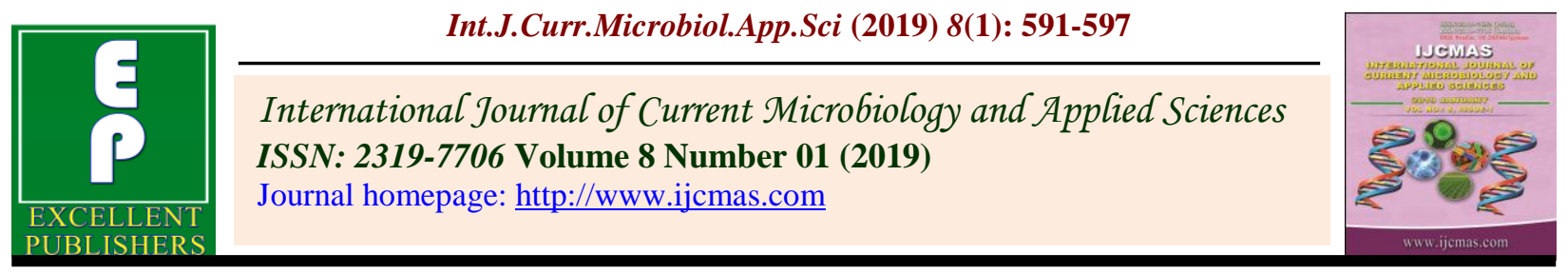

Original Research Article

https://doi.org/10.20546/ijcmas.2019.801.066

\title{
Adoption of Integrated Rice-Fish Farming System by Farmer of Ramchandrapuram
}

\author{
Bodi. Reena Rani ${ }^{1 *}$, Sameer Daniel ${ }^{1}$, Maddi. Harshitha ${ }^{1}$ and Sri Pakalapati Rambabu ${ }^{2}$ \\ ${ }^{1}$ College of Forestry, Sam Higginbottom University of Agriculture Technology and Sciences, \\ Naini, Allahabad (U.P.), India \\ ${ }^{2}$ ATMA (Ramchandrapuram), India \\ *Corresponding author
}

\section{A B S T R A C T}

Paddy is important cereal crop of Andhra Pradesh state, particularly East and West Godavari is considered as Rice bowl of Andhra Pradesh. It is cultivated under wide range

Keywords

Adoption,

Integrated

Rice-Fish farming

Farmer

Article Info

Accepted:

07 December 2018

Available Online:

10 January 2019 of soils and climatic conditions. It is grown in black soils as well as heavy clay loam soils. In East Godavari district total rice production area is 4.23 /ha. The major varieties grown in Ramchandrapuram mandal are MTU-1010, PLU-1100. More than $70 \%$ of the Indian farming community own less than one hectare of land. They belong to the category of small and marginal farmers. Such farmers feel that, except going for a single cropping system (like Paddy in canal irrigated lands, Groundnut in rainfed areas) there is hardly any possibility of trying new practices or methods for farm improvement. To address the needs of sustainable farming of such small and marginal farmers, an integrated farming model has been developed with low cost. The model emphasize the significance of four important sectors i.e., Agriculture, Fisheries, Horticulture and Animal Husbandry thus highlighting the concept of integrating one with another in assuring better yields and results to farmers who are eking their livelihood in these sectors. This model has been tried out in the field of the beneficiary farmer Sri G. Venkateswara Babu Rao, resident of Kapavaram village \& mandal of Ramachandrapuram block, East Godavari District.

\section{Introduction}

Though the practice of rice-fish farming differs from country, they all follow the same principle of utilizing or recycling farm resources for production. The major differences in these farming systems are mainly the variations in the field design, species composition, stocking density, sizes, crops, crop rotation etc., usually three types of field designs which included the shallow trench system within the rice field as seen in
Philippines, Indonesia and China; pond refuge adjacent to rice field at one side and deep water rice field system are practiced in India. In these systems, different types of land modifications are done for keeping and rearing the fish. In Eastern Indian states, mainly pond refuge and trench system of rice-fish farming is following whereas broad bed-farrows system is popular in the Andamans. The state of Andhra Pradesh is known as "RICE BOWL OF INDIA", but now it's CHATTISGARH who have taken the place of Andhra Pradesh. 
The only reason behind that is the less income and high investments are obtaining from sole rice crop in their fields, so many farmers in these states especially the farmers who belong to districts of East Godavari and West Godavari which are predominantly called as "RICE BOWL OF ANDHRA PRADESH". These districts have a high source of water availability from river GODAVARI so the farmers are leaving traditional agriculture and converting their fields into fish ponds and obtaining huge profits from it, but these is the scenario of a decade before in those districts right now these fish ponds are converting into "INTEGRATED RICE AND FISH FARMING SYSTEMS", which not only became a profitable adaptation but also a forward step for utilization of resources and also a component of promoting "Blue-Green revolution".

\section{Materials and Methods}

\section{Locale of study}

The present study was carried out in Ramchandrapuram mandal in East Godavari district of Andhra Pradesh state as this is one of the major paddy growing areas of East Godavari district. About 0.16 lakh hectare area is under paddy crop in this district.

\section{Selection of Mandal}

There are 60 mandals in East Godavari district. Out of 60 mandals in East Godavari district, selection of Ramchandrapuram mandal is selected as ATMA Block manager of this mandal is promoting and guiding back farmers to adapt this integration method as income generation and sustainable farming.

Case study of farmer who have adopted integrated rice-fish farming system

The calculation of "Integrated Rice-Fish Farming System" of Sri Gundapaneni.
Venkateswara Babu Rao who have started IRFS in his field area of 1.7 acre from June, 2016 - April, 2017 under the supervision of Pakalapati. Ramababu (Block Technology Manager) of ATMA of Ramchandrapuram mandal of East Godavari district of Andhra Pradesh.

\section{Farm details}

Name of the farmer: Gundapaneni.

Sri Venkateswara Babu Rao

Field area: 1.7 acres; 1 acre for RICE, 0.5 acre for Fishes Trench.

Paddy varieties: RP Bio 226, RNR 15048.

Fish varieties: Grass Crap -

Ctenopharingodonidella

Catla - Catla catla

Rohu - Labeorohitha

Horticulture plants: Banana, Papaya, Coconut

Livestock: 2 Murrah Buffaloes

\section{Operations undertaken in fishes trench}

While weeding in rice field and after completion of that weeding process we will apply $200 \mathrm{~kg} /$ acre of GANIJAMRUTHAM.

In order to assure the level of bacterial development in fishes trench we need to increase level by applying Fermented Butter Milk/Thati Kallu/Jeevamrutham @ 6 Lt/ Spray.

\section{Vermicompost (100kg)}

Pseudomonas (11t) + Phosphobacteria (11t) + Azospiru

\section{Feeds for fishes}

Litter of Hen: $25 \mathrm{Kg} / 3$ Days

Rice Bran : $25 \mathrm{Kg} / 3$ Days

Ginger Paste: $2 \mathrm{Kg} / 2$ Months

Raw Turmeric Paste: 2Kg/ 4-6 Months 


\section{Organic supplements for field Neemasthra required materials}

jeevamrutham required items

Cow Dung - $5 \mathrm{Kgs}$

Cow Urine - 5 Lts

Water - 20 Lts

Handful of Soil - Forest Soil/Bunds Soil

Gypsum/Lime - 50 gms

\section{Methods of preparation}

Mix the cow urine and gypsum in 20lts of water in which $5 \mathrm{~kg}$ cow dung is tiedup in a cloth bag was kept for 12 hours to soak, stir the contents in mean intervals.

\section{Utilization}

Sprinkle this composition on the seeds which are ready for sowing as a part of seed treatment allow them to dry under shady area, such treated seeds will sprout in a healthy manner and will prevent seed borne diseases.

\section{Ghana Jeevamrutham required items}

Cow Dung - $10 \mathrm{Kgs}$

Cow Urine - 2-5 Lts

Jaggery - $2 \mathrm{Kgs}$

Pulses Flour- 2 Kgs (except Soya and Ground nut)

Forest Soil / Soil at Bunds- 2 Kgs

\section{Method of preparation}

All the components are mixed well using cow urine and that mixture was spread thoroughly as thin layer in a shady area. The mixture is allowed to dry for 7days and then dried layers are finely powdered.

This fine powder can be stored for 6months in a bag and can be used when required. This finely grounded powder is sieved in field area as this serve as a supplement for micro and macro nutrients

$\begin{array}{ll}\text { Cow Dung } & -2 \mathrm{Kgs} \\ \text { Cow Urine } & -10-15 \mathrm{Lts} \\ \text { Neem Leaves } & -10 \mathrm{Kgs} \\ \text { Water } & -200 \mathrm{Lts}\end{array}$

\section{Method of preparation}

$10 \mathrm{Kgs}$ of Neem leaves are grounded as paste and it was mixed in 200 lts of water. To that mixture add 10-15lts of urine. Finally add $2 \mathrm{Kgs}$ of Cow Dung and mix it with stick. This mixture was kept aside for 4-5 hrs by covering it with lid. This mixture is well stored and used at regular time intervals for better maintanance of crop.

\section{Results and Discussion}

Case study of integrated rice-fish farming system adopted by farmer of Ramchandrapuram of East Godavari District

This model has had its impact in two ways.

Firstly, better conservation and use of on-farm natural resources thus establishing natural ecosystem.

Secondly, this model has been able to generate money surplus every month in addition to family consumption.

Conservation and utilisation of on-farm natural resources - maintaining ecological equilibrium.

\section{Soil moisture conservation}

Bunding done across the slope, both on the boundaries and around the paddy plot reduced the speed of water flow, thus enabling moisture retention. The vegetation on the bunds helped in stabilising the bunds, preventing soil erosion besides providing fodder and green manure (Table 1). 
Table.1 Case study of integrated rice-fish farming system adopted by farmer of Ramchandrapuram of East Godavari district

\begin{tabular}{|c|c|c|c|c|c|c|c|c|c|c|}
\hline \multirow[t]{2}{*}{ SNo } & \multicolumn{10}{|l|}{ Crop details } \\
\hline & & $\begin{array}{l}\text { Paddy RP } \\
\text { BIO 226 } \\
\text { (kharif) }\end{array}$ & $\begin{array}{l}\text { Paddy } \\
\text { RNR } \\
15048 \\
\text { (Rabi) }\end{array}$ & Banana & Papaya & Coconut & $\begin{array}{l}\text { Red } \\
\text { gram }\end{array}$ & $\begin{array}{l}\text { Fish } \\
\text { (Grass } \\
\text { crap, } \\
\text { Catla, } \\
\text { Rohu) }\end{array}$ & Dairy & \\
\hline 1 & $\begin{array}{l}\text { Preparation of } \\
\text { land/trench }\end{array}$ & 2000 & 1500 & 0 & 0 & 0 & 0 & 2500 & 0 & 6000 \\
\hline 2 & Seed/sampling & 250 & 350 & 660 & 1200 & 1080 & 14 & 2100 & 0 & 5654 \\
\hline 3 & $\begin{array}{l}\text { Nurseries labour } \\
\& \text { transplantation } \\
\text { labour }\end{array}$ & 5100 & 5000 & 500 & 500 & 1200 & 300 & 0 & 0 & 12600 \\
\hline 4 & weeding & 3400 & 2900 & 0 & 0 & 0 & 0 & 0 & 0 & 6300 \\
\hline 5 & Manure/feed & 1000 & 800 & 350 & 100 & 0 & 0 & 0 & 0 & 2250 \\
\hline 6 & Pests \& diseases & 600 & 600 & 0 & 50 & 0 & 100 & 500 & 0 & 1850 \\
\hline 7 & Cost of irrigation & & & & & & & & & 24200 \\
\hline 8 & $\begin{array}{l}\text { Interest on } \\
\text { working capital }\end{array}$ & & & & & & & & & 4414 \\
\hline 9 & $\begin{array}{l}\text { Rental value of } \\
\text { own land }\end{array}$ & & & & & & & & & 5500 \\
\hline 10 & Depreciation & & & & & & & & & 594 \\
\hline 11 & $\begin{array}{l}\text { Interest on fixed } \\
\text { capital }\end{array}$ & & & & & & & & & 5066 \\
\hline 12 & Land revenue & & & & & & & & & 800 \\
\hline 13 & Insurance & & & & & & & & & 2500 \\
\hline 14 & $\begin{array}{l}\text { Inputed value of } \\
\text { family labour }\end{array}$ & & & & & & & & & 1500 \\
\hline 15 & $\begin{array}{l}\text { Harvest of crop } \\
\text { /fish }\end{array}$ & 1200 & 1200 & 0 & 0 & 0 & 200 & 3000 & 0 & 5600 \\
\hline 16 & Others & 0 & 0 & 0 & 0 & 0 & 0 & 1000 & 18000 & 19000 \\
\hline 17 & Yield & 938 & 825 & 540 & 1840 & 180 & 20 & 3300 & 26 & \\
\hline 18 & Unit $\operatorname{cost}(\mathrm{Rs})$ & 22 & 30 & 35 & 10 & 20 & 130 & 120 & 60 & \\
\hline 19 & $\begin{array}{l}\text { Gross } \\
\text { income(Rs) }\end{array}$ & 20636 & 24750 & 18900 & 18400 & 3600 & 2600 & 396000 & 75600 & 560486 \\
\hline 20 & $\begin{array}{l}\text { Total } \\
\text { expenditure }\end{array}$ & & & & & & & & & 70268 \\
\hline 21 & Net profit & & & & & & & & & \\
\hline 22 & Cost A & & & & & & & & & 63268 \\
\hline 23 & COST B & & & & & & & & & 68768 \\
\hline 24 & COST C & & & & & & & & & 70268 \\
\hline & Gross Income & 560486 & & & & & & & & \\
\hline & al Expenditure & 63268 & & & & & & & & \\
\hline & Net Profit & 70268 & & & & & & & & \\
\hline & st Benefit Ratio & $1: 7$ & & & & & & & & \\
\hline
\end{tabular}


The farm pond is at the lowest point on the field and the excess water which would have otherwise gone waste gets collected in the small pond. The harvested water is used for irrigating horticulture crops.

\section{Soil fertility}

The crop residues on the bunds and the animal wastes have been the major source for composting manure. Thus the soil fertility was managed by lowering chemical inputs and more of organic farm litter.

\section{Income generation}

Livestock rearing started with two Murrah, Jersey breed buffaloes The Murrah breed buffalo produced 6 litres milk per day. These will substitute the milk requirement by family members.

\section{Other farm enterprises}

Pisciculture is one of the main activity that yielded incomes by raising fish in the trench. The farm pond served both as a nursery pond for spawn to be stocked well as a watershed to collect excess water and rain water.

\section{Other benefits}

Over a couple of months, besides the above mentioned benefits, the farm family can benefit from production of fruits from horticulture plants. They can serve nutritional needs and also provide some cash income. These types of enterprises provide labour for the family over the entire year.

Productivity, Profitability, Potentiality or sustainability, Balanced food, Adoption of new technology, Saving energy, Meeting fodder crises, Solving fuel and timber, Environmental safety, Recycling, Income round the year, Employment generation, Agro-industries, Increasing Input efficiency.
The model depicts a fine blend of all the farm enterprises where in each and every component feeds into the other, thus making efficient utilization of products, by-products and also wastes generated on the farm. Multicropping systems always gives higher returns than Mono crop as such it can be replicated in other parts of the district and across the state based on the feasibility of the water source.

\section{References}

Ali, A.B. (1992). Rice-fish farming in Malaysia, Fertility and productivity. In C.R. dela Cruz, C Lightfoot, B.A Costa Pierce, V.R. Carangal and M.P Bimbao (eds.) Rice-fish research and development in Asia, ICLARM Conf. Proc:pp.24,457.

Costa Pierce, B. A., Dela cruz C.R., Lightfoot, C., Carangal, V. R. and M.P, Bimbao. Eds. (1992). Rice-fish research and development in Asia, International centre for living Aquatic Resources Management, Manila, Phillippines. pp. 261-281.

Dube, K. (1995). Integrated agriculture. A systematic approach farming system, Indian farming, 45(8): 12-15.

Fagi, A.M., Suriapermal, S. and Syamsiah, I. (1994). Rice-fish farming research in low land areas: the West Java case. In Rice-fish research and development in Asia. ICLARM Conf. Proc. 24, pp: 325331.

Fang, Xiuzhen., Guo, Xianzhen., Wang, Jikun., Fang, Yingxue. and Liu, Zhiyun (1994). A preliminary study on aerobic heterotrophic bacteria in semi- intensive polyculture fish pond. In: The selected papers of basic integrated fish farming theory and fishing bioeconomic research, pp. 240-248.

Ghosh, A. and Saha, S.K. (1980). Scope of Paddy cum fish culture in India, In J.I.Furtado (ed.) Tropical ecology and development part 2. (Proc. V. Internat. 
Symp. Trop ecol, 16-21 April 1979, Kulalumpur, Malaysia). International society of Tropical Ecology, Kualalumpur. pp. 1009-1015.

Ghosh, A., and P.K, Chakrabarti. (1990) Rice-fish production system: A viable technology for coastal wetland management in West Bengal. In, rice in wetland ecosystem. Ed, R.R, Nair., K.P.V, Nair and C.A, Joseph,. Kerala Agricultural University, pp. 261-267.

Ghosh, A. (1992). Rice fish farming development in India: Past, Present and Future. In C.R. ela Cruz, C. Lightfoot, B.A. Costapierce, V.R. Carangal and M.P. Bibao (eds) Rice fish research and development in Asia. ICLARM Conf. Proc. 24, 457. pp. 27-43.

Halwart, M. (1994). Fish as biocontrol agents in rice. The potential of common carp Cyprinus carpio (L) and Nile tilapia Oreochromis niloticus (L) Trop Agroecol. Weikersheim, Germany Margraf Verlag. 8:169.

Hu Bautong Zhou Enhua. (1990). Selected papers of Fresh water Fisheries Research Jun, Fresh water Fisheries Research Centre, Chinese Academy of Fisheries Sciences, Asian - Pacific Regional Research and Training Centre for Integrated fish Farming. pp. 97-104.

Khoo, K. H. and E. S. D, Tan (1980). Review of rice- fish culture in Southeast Asia, ICLARM, Conf. Proc. 4, pp. 1-14.

Li- Kangmin. and Paw-Yinkhe. (1994). The selected paper of basic integrated fish farming theory and fishery, Bioeconomic research. Pp. 104-127

Lightfoot, C A., Roger., A.G, Caugaun. and C.R, De La Cruz. (1990). A fish Crop may improve rice yields and rice fields, In Fish as a new crop in international agricultural research. Nagar, ICLARM, pp. 12-13.

Moody Keith. (1992). Fish crustacean- Weed interactions. In Rice-Fish Research and development in Asia., Ed.C. R, Dela Cruz., C, Lightfoot., B.A, Costa Pierce., Muraleedharan, P.K. (1981). Resource use efficiency in rice cultivation on low lying lands in Kerala, Pillai K P (ed). Agricultural development in Kerala, Agricole Publishing Company. pp. 2128.

Nie, D. and J, Wang. (1981). Studies on rice and fish mutualism. Fishery techniques and information. 6: 1-3.

Nie, D., Y, Chen. and J, Wang. (1992). Mutualism of Rice and Fish in rice fields. In Rice-fish research and development in Asia (Ed) C.R, Dela Cruz., C, Lightfoot., B. A, CostaPierce., V.R, Carangal and M.P.Bimbao. ICLARM Conf., Proc. 24, pp. 173-175.

Padmakumar, K.G., Krishnan, A. and Nair, R. R. (1993). Production maximization through integrated farming approach for low lands of Kerala. Paper presented at the third India Fisheries Forum, Oct1114, 1993 Pan tanger. pp. 49-52.

Rajendran, C.G., Abraham, S.F., Mrithynjayan, P.S., Thampy, D.M. and Jose, M.M(1981) Studies on fish culture along with paddy Pokkali fields of Kerala. All India Symposium on fresh water biology. pp.17-18, 148-159.

Rajput, U.V. 2004.Identification of indigenous agricultural practices and its adoption by farmers M.Sc. Thesis (unpub.) Dr. PKDV, Akola.

Sevilleja, R.C. and Lopez, E.A. (1986). Rotational cropping patterns for rice and fish. FAC progress report, Freshwater aquaculture centre, Central Luzon State University, Neuva Eeija, Philippines. pp. 5-7.

Sevilleja, R.C. (1986). Alternate and modified management system for rice fish culture. In Report of 17th Asian Rice Farming systems working Group, Ministry of Agriculture and Food and 
IRRI, Philippines. Pp. 28-36.

Thakre, I. S. 1980. Fertilizer utilization behaviour of the farmers and constraints in adoption. M. Sc. Thesis (Unpub.) Dr. PDKV, Akola.

Vijayalayan, R. 2001. A study of awareness knowledge and adoption of eco-friendly agricultural practices in rice. $M$. Sc. Thesis (Unpub.) Agricultural College and Research Institute, Coimbatore. Pp.
88-90.

Wang, J. (1992). Methodology in extending rice-fish farming system in China. In: Rice-fish research and development in Asia (Ed). C.R de La Cruz, C, Lightfoot., B.A, Costa-Price., V.R, Carangal and M.P, Bimbao. ICLARM conf. proc. 24: 325-331.

\section{How to cite this article:}

Bodi. Reena Rani, Sameer Daniel, Maddi. Harshitha and Sri Pakalapati Rambabu. 2019. Adoption of Integrated Rice-Fish Farming System by Farmer of Ramchandrapuram. Int.J.Curr.Microbiol.App.Sci. 8(01): 591-597. doi: https://doi.org/10.20546/ijcmas.2019.801.066 